bisection of the molecule. Thus, the parametric resonance technique is effective for less-invasive high-speed AFM imaging.

\section{P-256 超音波高速原子間力顕微鏡による表面下構造のイメージング}

Visualization of subsurface structures by high-speed ultrasonic force microscopy

Hiroki Watanabe (1), Takayuki Uchihashi (2), Toshio Ando (2) ((1) Department of Mathematics and Physics Sciences, Grad School of Natural Science and Technology, kanazawa Univ.: (2) School of Mathematics and Physics, College of Science and Engineering , kanazawa Univ.; CREST/JST

Most of biological processes occur in the interior of the cell. Therefore, we need non-invasive imaging techniques that allow high-speed and high-resolution visualization of dynamic processes of molecules and organelles in the cell interior. Optical microscopy has often been used to image intracellular events but its resolution is low. Very recently, it has been demonstrated that atomic force microscopy (AFM) combined with ultrasound holography can image subsurface structures at nanometer resolution, even for the cell. High-speed AFM has already succeeded in imaging dynamic processes of single biomolecules unde physiological conditions. Here we began a pilot study of combining ultrasound techniques with high-speed AFM aiming at high-resolution visualization of dynamic intracellular processes. In the first step, we attempted to replicate the ultrasound holography AFM experiments according to published results. However unlike the previous studies, we performed the experiments under liquids. Using samples of gold particles buried deeply beneath a polymer layer and stripepatterned silicon wafer fully covered with a polymer layer, we could image their subsurface structures but noticed problems arising from the in-liquid condition. Now, we are developing a new approach to the in-liquid subsurface imaging to overcome the problems.

\section{P-257高速原子間力顕微鏡による探針試料間の相互作用力の検出感度の \\ 向上}

Enhancement of detection sensitivity of tip-sample interaction in high-speed AFM

Masato Yoshida (1), Takayuki Uchihashi (2), Toshio Ando (2) ((1) Department of Mathematics and Physics, Grad School of Natural Science and Technology, kanazawa Univ.: (2) School of Mathematics and Physics, College of Science and Engineering, Kanazawa Univ.CREST/JST)

The scan speed of AFM has been significantly improved. High-speed AFM now allows us to visualize dynamic behavior of individual protein molecules in action. However, further compatibility of high-speed imaging with low-invasive imaging remains a challenge. We have been attempting to minimize tip-sample interaction force by developing a dynamic PID controller, a fast scanner, and others. By these efforts, the tip-sample interaction has been significantly reduced but further reduction is still necessary to widen the scope of samples to be imaged by highspeed AFM.

We have been using a fast amplitude detector which holds the peak and bottom voltages at every half oscillation cycle. This is the fastest detector but contains noise arising from thermal motion of a cantilever. To reduce the noise, we here developed a fast and less noisy amplitude detector based on a Fourier method. The amplitude detector is composed of an A/D converter, a digital signal processor (DSP) and a D/A converter. The DSP calculates the Fourier coefficients of the cantilever's fundamental resonant frequency and then reconstructs the amplitude and phase of cantilever oscillation. The thermal noise of the cantilever with low $Q$ value is significantly reduced by very narrow-band filtering, and thereby, the tip-sample interaction is also reduced. By combining this new detector and a parametric excitation of a cantilever, the interaction force is further reduced

\section{P-258誤差を含む混合蛍光スペクトルに対するスペクトル分離の有効性} の検討

The validity of linear unmixing of spectra containing serially correlated error terms.

Sosuke Iwai (1), Taro Uyeda QP (2) ((1) Faculty of Education, Hirosaki University: (2) Research Institute for Cell Engineering, National Institute of Advanced Industrial Science and Technology)

Spectral imaging with spectral unmixing procedures extends the possibilities to distinguish signals from multiple fluorophores with highly overlapping spectra and thus the possibilities of multicolor fluorescence imaging, including FRET imaging and simultaneous imaging of multiple fluorescent proteins. Generally, the measured spectrum is separated into contributions from different fluorescent components by least squares regression methods (known as "linear unmixing") However, it is known that the estimators of least square regression may have significant errors if the errors in the measured spectrum are serially correlated as is often the case with living cells containing a large amount of autofluorescence. In this study, we have estimated the extent of such errors with regard to the ratio values for fluorescent ratiometric probes. The estimation suggested that the ratio errors depend both on the extent of the errors of the measured spectrum and the angles between the spectral vectors of the fluorescent components. To confirm the utility of the estimation, we applied it to the spectroscopic evaluation of the GFPbased ratiometric strain sensor (Iwai et al., 2008), to reveal interaction between myosin II and F-actin in Dictyostelium cells. The estimation of the errors enabled us to demonstrate that small differences in the fraction of myosin bound to F-actin under various conditions are significant. Specifically, we concluded that the formation of myosin filaments as well as affinity of each myosin head to F-actin significantly affects the interaction of the protein with F-actin in cells. The estimation method we developed here may provide a useful means to evaluate the efficiency of spectral unmixing.

\section{P-259 シアノバクテリア細胞周期におけるクロモソーム DNA 形状変化 の観察}

Observation of bulk structural change of chromosomal DNA during the cell cycle of Synechococcus elongatus PCC 7942

Yasuko Kaneko (1), Yukiko Seki (1), Sayuri Hagiwara (1), Koji Nitta (2), Kuniaki Nagayama (3) ((1) Saitama University: (2) Terabase Inc.: (3) Okazaki Inst. Integrative Biosci., Natl. Inst. Natural Sci.)

Synechococcus elongatus PCC 7942 contains 2 to 5 copies of chromosomal DNA per cell. The number of copies increases during cell elongation and the elongated cells divide synchronously under regular light/dark cycles. For this study, bulk structural change of chromosomal DNA during the cell cycle was visualized with Hoechst 33342 staining using fluorescent microscopy, and also by phase contrast transmission electron microscopy.

Synechococcus elongatus PCC 7942 cells were cultured on agar plates under $12 \mathrm{~h}$ light/ $12 \mathrm{~h}$ dark cycles. Vigorously growing cells were collected every $2 \mathrm{~h}$ and stained with Hoechst 33342. With fluorescent microscopy, the stained DNA displayed a mostly diffuse appearance throughout the cells, except between 6 and $10 \mathrm{~h}$ of the light phase of the cycle, when chromosomal DNA gradually condensed into distinct separate balls, which then transformed into thick wavy strands. These subsequently separated into two portions and cell division followed. The Hoechst 33342 stained cells were also observed by phase contrast TEM. The stained cells of the condensed DNA stage were rapidly frozen in liquid ethane and transferred to the specimen chamber, which was cooled with liquid helium. The ice embedded cells were observed with a $300 \mathrm{kV}$ TEM equipped with Hilbert differential contrast phase plate. Hoechst 33342 stained DNA appeared electron dense in whole ice embedded cyanobacterial cells both with and without phase plate. Various configurations of DNA strands were clearly visualized when the HDC phase plate was applied.

\section{P-260 光学顕微鏡（対物外アポダイズド位相差）と電子顕微鏡のインタ ラクティフ観察による、細胞核内部を運動する構造の同定}

Interactive observation of optical and electron microscopy revealed moving particles in the nucleus.

Kaoru Katoh (1), Ayako Kojima (1), Emiko Kobayashi (2), Kazunori Kawasaki (2) ((1) Neurosci. Res. Inst, AIST: (2) Cell Eng. Res. Inst,, AIST)

see 3TP3-05

\section{P-261 II 型 DNA トポイソメラーゼの手品のような反応を直接みる}

Direct Observation of DNA Unlinking Magic by a Type-II DNA Topoisomerase.

Katsunori Yogo (1), Taisaku Ogawa (1), Saki Obata (1), Gen Nakajima (1), Junpei Suzuki (1), Kazuhiko, Jr. KInosita (1) ((1) Department of Physics, Waseda University)

$$
\text { see 3TP3-02 }
$$

\section{P-262 細胞内 mRNA の長時間観察を可能にする蛍光核酸プローブ}

Long-term monitoring of intracellular mRNA by hybridizationsensitive fluorescent nucleotide probe

Takeshi Kubota (1), Shuji Ikeda (1), Hiroyuki Yanagisawa (1), Mizue Yuki (1), Akimitsu Okamoto (1) ((I) ASI, RIKEN)

see 3TP3-03

\section{P-263 モーター蛋白質で駆動するディスプレイの開発 \\ Development of a display driven by microtubule motor protein}

Susumu Aoyama (1), Masahiko Shimoike (1), Yuichi Hiratsuka (2) ((1) School of Materials Science, JAIST: (2) School of Materials Science, JAIST; JST PRESTO) 